\title{
Bathymetric zonation of deep-sea macrofauna in relation to export of surface phytoplankton production
}

\author{
Chih-Lin Wei ${ }^{1, *}$, Gilbert T. Rowe ${ }^{2}$, G. Fain Hubbard ${ }^{2, \mathrm{~T}}$, Amélie H. Scheltema ${ }^{3}$, \\ George D. F. Wilson ${ }^{4}$, Iorgu Petrescu ${ }^{5}$, John M. Foster ${ }^{6}$, Mary K. Wicksten ${ }^{7}$, \\ Min Chen ${ }^{8}$, Roe Davenport ${ }^{7,+}$, Yousria Soliman ${ }^{2}$, Yuning Wang ${ }^{9}$ \\ ${ }^{1}$ Department of Oceanography, Texas A\&M University, College Station, Texas 77843, USA \\ ${ }^{2}$ Department of Marine Biology, Texas A\&M University at Galveston, Galveston, Texas 77551, USA \\ ${ }^{3}$ Woods Hole Oceanographic Institution, Woods Hole, Massachusetts 02543, USA \\ ${ }^{4}$ Australian Museum, Sydney, New South Wales 2010, Australia \\ ${ }^{5}$ National Museum of Natural History 'Grigore Antipa', Bucharest 011341, Romania \\ ${ }^{6}$ Department of Coastal Sciences, University of Southern Mississippi, Ocean Springs, Mississippi 39564, USA \\ ${ }^{7}$ Department of Biology, Texas A\&M University, College Station, Texas 77843, USA \\ ${ }^{8}$ ExxonMobil Biomedical Sciences, Annandale, New Jersey 08801, USA \\ ${ }^{9}$ Oceanside Biology Lab, San Francisco Public Utilities Commission, San Francisco, California 94132, USA
}

ABSTRACT: Macrobenthos of the deep, northern Gulf of Mexico (GoM) was sampled with box cores $\left(0.2 \mathrm{~m}^{2}\right)$ along multiple cross-depth transects extending from depths of $200 \mathrm{~m}$ to the maximum depth of the basin at $3700 \mathrm{~m}$. Bathymetric (depth) zonation of the macrofaunal community was documented for 6 major taxa (a total of 957 species) on the basis of shared species among geographic locations; 4 major depth zones were identified, with the 2 intermediatedepth zones being divided into east and west subzones. Change of faunal composition with depth reflects an underlying continuum of species replacements without distinct boundaries. The zonal patterns correlated with depth and detrital particulate organic carbon (POC) export flux estimated from remotely-sensed phytoplankton pigment concentrations in the surface water. The Mississippi River and its associated mesoscale eddies, submarine canyon, and deep sediment fan appear to influence the horizontal zonation pattern through export of organic carbon from the ocean surface and the adjacent continental margin. On the local scale, near-bottom currents may shape the zonation pattern by altering sediment grain size, food availability, and larval dispersal. This study suggests a macroecological relationship between depth, export POC flux, and zonation; parsimonious zonal thresholds need to be tested independently for other continental margin ecosystems.

KEY WORDS: Northern Gulf of Mexico - Deep sea · Macrofauna - Zonation · Biogeography · Community structure $\cdot$ POC export flux $\cdot$ Macroecology

Resale or republication not permitted without written consent of the publisher

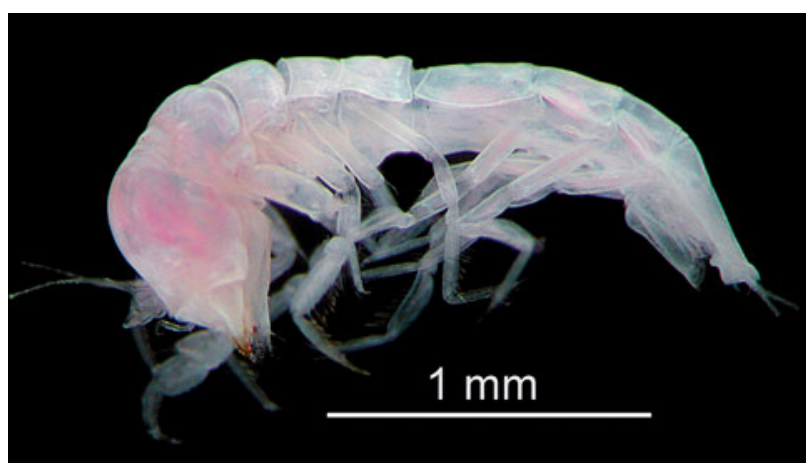

Thaumastasoma species 521 (Crustacea; Isopoda; Nannoniscidae), a typical species of the lower continental slope.

Photo: George D. F. Wilson

\section{INTRODUCTION}

The extreme change of depth across continental slopes is among the largest of environmental gradients. The rapid change of faunal composition down the continental margin has fascinated deep-sea ecologists for over a century and remains a difficult and elusive pattern to explain. Depth zonation was first noticed during the 'Challenger Expedition', with a distinct biota on the shelves and in the abyss, and a faunal transition zone in between. The boundary of this faunal zone has been defined as the depth of maximum 
faunal change (Ekman 1953, Menzies et al. 1973). In order to distinguish boundaries between zones, as opposed to continuous replacement of species with depth, 'zonation' should be described as a non-repeating, sequential species replacement, in which all or some of the species have restricted ranges of distribution (Rex 1981, Carney et al. 1983, Carney 2005). A faunal boundary is best described as areas of rapid faunal change encompassing an area of slow faunal change across depths (Hecker 1990, Gage \& Tyler 1991).

Studies of zonation in the deep sea have focused primarily on the general patterns of megafaunal assemblages (Hecker 1990, Cartes \& Carrasson 2004, Wei \& Rowe 2009) or distribution and abundance of a particular taxon, such as fishes (Jacob et al. 1998, Powell et al. 2003), decapod crustaceans (Cartes \& Sardà 1993, Wicksten \& Packard 2005), echinoderms (Howell et al. 2002), and holothurians (Billett 1991). Zonation studies on macrofaunal assemblages are relatively sparse (Grassle et al. 1979, Rowe et al. 1982, Gage et al. 2000) and have mostly dealt with individual taxa (Rex 1977, Cartes \& Sorbe 1997, Pérez-Mendoza et al. 2003, Olabarria 2005, Aldea et al. 2008). Most previous investigations were carried out along a single narrow depth transect and reported a vertical zonation across isobaths. Horizontal zonation has also been suggested, presumably due to changes in physical or chemical conditions within geographical areas (Hecker 1990).

In the Gulf of Mexico (GoM), deep-sea zonation studies have focused on the depth distribution of benthic foraminifera and megafauna, with sporadic studies on benthic macrofauna. Culver \& Buzas $(1981,1983)$ compiled published foraminifera data from 1918 to 1978 in the GoM and established Upper-Bathyal (200 to $500 \mathrm{~m}$ ), Middle-Bathyal (500 to $1000 \mathrm{~m}$ ), and LowerBathyal (1000 to $2000 \mathrm{~m}$ ) Zones on the continental slope (Culver 1988). The prominent foraminiferan zones have been related to water masses (Culver \& Buzas 1981, Denne \& Sen Gupta 1991) in which the UpperBathyal Zone was associated with the temperature gradient, oxygen supply, and organic flux, and the Middle and Lower-Bathyal Zone were correlated with organic flux to the seafloor (Loubere et al. 1993).

Pequegnat (1983) proposed 5 megafauna zones in the northern GoM, including Shelf/Slope-Transition (150 to $450 \mathrm{~m})$, Archibenthal (475 to $950 \mathrm{~m})$, UpperAbyssal (975 to $2250 \mathrm{~m}$ ), Meso-Abyssal (2275 to $3200 \mathrm{~m}$ ), and Lower-Abyssal Zone (3225 to $3850 \mathrm{~m}$ ). The highest faunal turnover was at $1000 \mathrm{~m}$ (Pequegnat et al. 1990). Gallaway (1988) merged the Abyssal Zones and then extended the Archibenthal Zone to a deeper depth of about $1350 \mathrm{~m}$. The distribution pattern of macrofauna was different from the megafauna. Both the Shelf/ Slope-Transition (300 to $700 \mathrm{~m}$ ) and Archibenthal Zone
(700 to $1650 \mathrm{~m}$ ) for macrofauna extended to deeper depths than those for megafauna, while the Abyssal Zone (2000 to $3000 \mathrm{~m}$ ) was limited by lack of samples on the abyssal plain. A comparison between principal component analysis (PCA) classification on physicochemical parameters and the biological classification suggested that bottom temperature, salinity, hydrocarbon level, and sediment characteristics were important factors relating to the zonation pattern of macrofauna.

The cause of depth zonation has been attributed to sunlight (or absence of), temperature, pressure, water masses, and most importantly availability of food (Carney et al. 1983, Carney 2005). The seafloor community relies on the sinking detrital carbon from the euphotic zone (Gage \& Tyler 1991). The downward flux of fecal pellets or marine snow is consumed by the mid-water community and declines exponentially with depth (Suess 1980, Pace et al. 1987, Rex et al. 2006). In the northern GoM, the flux of particulate organic carbon (POC) not only declines with depth, but is 2 times higher in the northeast than in the northwest GoM (Biggs et al. 2008). The depth-dependent detritus flux from surface production has been linked to benthic standing stocks (Johnson et al. 2007) and taxon composition (Ruhl et al. 2008). However, the relationship between the export POC flux and species composition or faunal zonation is still poorly understood.

In this study, we used a broad, systematic survey to examine the zonation pattern of the entire macrofaunal assemblage with several potentially interacting communities. We propose that faunal zonation is not only taking place across isobaths, but also horizontally from the northeast to the northwest GoM due to the influence of the Mississippi River. The horizontal productivity gradient in the northern GoM provides a unique opportunity to tease out the potential effects of food supply on zonation independent of depth by examining the relationship between zonation (species composition) and the remotely sensed export POC flux (Biggs et al. 2008), coupled with new information on bottom water properties (Jochens \& DiMarco 2008), sediment geochemistry (Morse \& Beazley 2008), and anthropogenic contaminants (Wade et al. 2008).

\section{MATERIALS AND METHODS}

Sampling program. As part of the Deep Gulf of Mexico Benthos (DGoMB) study, benthic macrofauna was sampled from 2000 to 2002 (Rowe \& Kennicutt 2008). A total of 51 locations from depths of 200 to $3700 \mathrm{~m}$ (Fig. 1; Table S1 in the supplement at www.int-res. com/articles/suppl/m399p001_app.pdf) were sampled with GOMEX box cores (sampling area $=0.17 \mathrm{~m}^{2}$; Boland \& Rowe 1991). At least 5 cores were deployed 


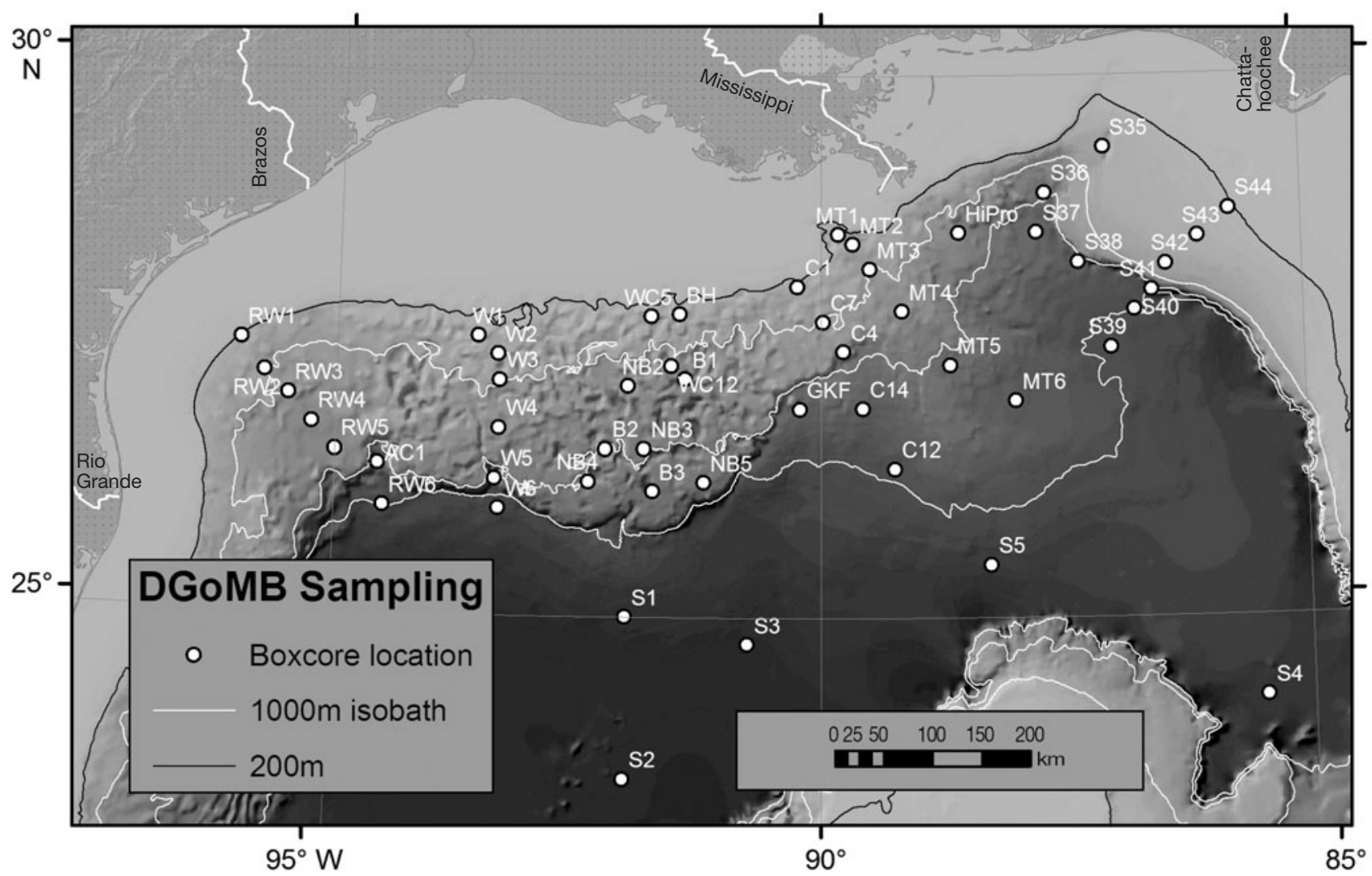

Fig. 1. Box core locations during the Deep Gulf of Mexico Benthos (DGoMB) study. Black line: $200 \mathrm{~m}$, white lines: $1000 \mathrm{~m}$ isobaths. Abyssal plain sites (S1 to S5) sampled in summer 2002. Other slope sites sampled in summer 2000, and partially re-visited in summer 2001. Derived from French \& Schenk (2006)

at each station, and overall 271 cores were taken, which equals over $46 \mathrm{~m}^{2}$ of seafloor sampled. The top $15 \mathrm{~cm}$ of sediments were sieved on a $300 \mu \mathrm{m}$ screen. The retained material was fixed in $10 \%$ buffered formalin diluted with filtered seawater. Samples were stained with $5 \%$ Rose Bengal for at least $24 \mathrm{~h}$, and then rinsed with fresh water. The stained samples were sorted into major taxonomic groups and transferred to $70 \%$ ethyl alcohol for permanent preservation. Six major macrofaunal taxa, including amphipods (analyzed by J.M.F. and Y.S.), aplacophorans (A.H.S.), bivalves (M.K.W., R.D., and M.C.), cumaceans (I.P.), isopods (G.D.F.W.), and polychaetes (G.F.H. and Y.W.), were separated into 957 putative species $(27 \%$ named species and $73 \%$ undescribed species) by the named taxonomists.

Environmental data selection. Not all environmental data had complete coverage in our study area. Only the data that covered $>90 \%$ of the sites and were not auto-correlated (Pearson's correlation, $\rho<0.9$ ) were retained for the analysis. A total of 12 variables including depth, export POC, temperature, salinity, dissolved oxygen, fluorescence, backscatter, particulate material, percent sand, percent silt, percent clay, total polycyclic aromatic hydrocarbons (PAHs; Table 1) and 16 trace metals ( $\mathrm{Al}, \mathrm{Ba}, \mathrm{Be}, \mathrm{Ca}, \mathrm{Cr}, \mathrm{Cu}, \mathrm{Fe}, \mathrm{Mg}, \mathrm{Mn}, \mathrm{Na}$, $\mathrm{Ni}, \mathrm{Si}, \mathrm{Sr}, \mathrm{Ti}, \mathrm{V}$, and $\mathrm{Zn}$ ) were retained. Export POC flux to the seafloor was calculated using an exponential decay model (flux $[z]=3.523 \times \mathrm{NPP} \times z^{-0.734}$ ), where $z=$ depth and NPP = satellite-based net primary production (Pace et al. 1987). Detailed methodology can be found in Biggs et al. (2008). The complete list of environmental and macrofauna data are archived in the US Department of the Interior, Minerals Management Service and the Ocean Biogeographic Information System (OBIS).

Data analysis. Bray-Curtis similarity (Bray \& Curtis 1957) was calculated on 4th-root transformation of average species abundance per box core to define relationships of the faunal composition between all sites (Clarke \& Warwick 2001). The purpose of this transformation is to accentuate the effect of rare species. The intra-location resemblance was subjected to group-average linkage cluster analysis. A similarity profile test (SIMPROF) was performed on a null hypothesis that a specific sub-cluster can be recreated by permuting the entry species and samples. The significant branch (SIMPROF, p < 0.05) was used as a prerequisite for defining the faunal zones. 
Non-metric multidimensional scaling (MDS) was conducted on the resemblance matrix to examine the sample relationship on a 2-dimensional plane. The average similarities within a faunal zone and dissimilarity between faunal zones were broken down to similarity percent contribution (SIMPER) of each species. The species that contributed the most within the zone and species that discriminate 1 zone from another were examined as characteristics of the faunal zones.

The environmental data were logarithm transformed, normalized (divided by SD), and computed for Euclidean distances. The intra-location distances were used as a proxy to characterize the seafloor environment and correlated with the intra-location faunal resemblance using Spearman's rank correlation (RELATE). A principal component analysis (PCA) was conducted on the environment distance matrix to examine the relationship of the seafloor properties among the biotic zones. The 10 best subsets of environmental variables (highest correlations with faunal resemblance) were selected from all possible combinations (BIO-ENV).

One-way analysis of similarity (ANOSIM) was performed on the same distance matrix to test the null hypothesis that the multivariate environmental data were not different in the pre-defined faunal zones. The test statistic R (usually between 0 and 1 ) is a measurement of the degree of group separation. To avoid a Type 1 error, the ANOSIM pairwise comparisons between faunal zones employed a conservative significance level $(\alpha=1 \%)$.

The best subset of variables determined by BIOENV was subjected to a constrained type of cluster analysis (LINKTREE) on the same set of faunal resemblance. The dendrogram was constructed by successive binary partitions of biotic community samples. Each

Table 1. RELATE tests on the selected environmental data. A Spearman's rank correlation coefficient was calculated between individual variables and faunal similarity. POC: particulate organic carbon, PAH: polycyclic aromatic hydrocarbon, PDR: precision depth recorder

\begin{tabular}{|c|c|c|c|c|}
\hline Variable & e $\rho$ & $\mathrm{p}$ & Description & Gear \\
\hline POC & 0.697 & $<0.001$ & Export POC flux (mg-C $\left.\mathrm{m}^{-1} \mathrm{~d}^{-1}\right)$ & SeaWifs satellite \\
\hline DEP & 0.671 & $<0.001$ & Water depth $(\mathrm{km})$ & PDR \\
\hline SAL & 0.451 & $<0.001$ & Salinity (psu) & CTD \\
\hline MET2 & 0.446 & $<0.001$ & Trace metal principal component 2 & Box core \\
\hline $\mathrm{DO}$ & 0.415 & $<0.001$ & Dissolved oxygen $\left(\mathrm{ml} \mathrm{l}^{-1}\right)$ & CTD \\
\hline TEM & 0.394 & $<0.001$ & Potential temperature $\left({ }^{\circ} \mathrm{C}\right)$ & CTD \\
\hline MET1 & 0.262 & $<0.001$ & Trace metal principal component 1 & Box core \\
\hline FLU & 0.232 & $<0.001$ & Relative fluorescence (volts) & CTD \\
\hline SAN & 0.177 & 0.003 & Percent sand $(\%)$ & Box core \\
\hline SIL & 0.12 & 0.019 & Percent silt (\%) & Box core \\
\hline PAHs & 0.062 & 0.14 & Total PAH with perylene $\left(\mu g^{-1}\right)$ & Box core \\
\hline $\mathrm{BAC}$ & 0.039 & 0.23 & Relative backscatter $\left(\mathrm{mg} \mathrm{l}^{-1}\right)$ & CTD \\
\hline $\mathrm{PM}$ & -0.002 & 0.482 & Particulate material $\left(\mathrm{mg} \mathrm{l}^{-1}\right)$ & Niskin bottle \\
\hline CLA & -0.025 & 0.635 & Percent clay $(\%)$ & Box core \\
\hline
\end{tabular}

division was determined by a threshold on 1 of the environmental variables that maximized the betweengroup variance (largest ANOSIM R statistic). The binary split was continued until SIMPROF suggested the new branch was not significant ( $p \geq 0.05$ ).

The multivariate zonation and environmental analyses were conducted using PRIMER v6 (Clarke \& Warwick 2001, Clarke et al. 2008). Bathymetric maps were generated using ArcGIS 9.0.

\section{RESULTS}

\section{Zonation pattern and faunal distribution}

Hierarchical cluster analysis and SIMPROF revealed 13 significant groups (Fig. 2, p < 0.05), which can be categorized as 6 faunal zones (Zones 1, 2E, 2W, 3E, 3W, 4 ) and 2 independent locations (Green Knoll Furrows [GKF] and WC5). Zones 1, 2 (including 2E and 2W), 3 (including $3 \mathrm{E}$ and $3 \mathrm{~W}$ ), and 4 were separated at the $25 \%$ similarity level; Zones $2 \mathrm{E}$ and $2 \mathrm{~W}$ were separated at the $30 \%$ similarity level; and Zones $3 \mathrm{E}$ and $3 \mathrm{~W}$ were separated at the $29 \%$ similarity level. Due to the low faunal similarities with other stations (20.1 to $22.6 \%$ ), the independent stations were not included in any faunal zone. The MDS ordination (Fig. 3, stress $=0.17$ ) reflects an underlying continuum without distinct zonal boundaries along the depth gradient. The negative direction of the $x$-axis follows from the shallow toward the deeper faunal zones. The $y$-axis separates Zone $2 \mathrm{E}$ from $2 \mathrm{~W}$ and Zone $3 \mathrm{E}$ from $3 \mathrm{~W}$. Zones $2 \mathrm{E}, 3 \mathrm{E}$, and the east side of Zone 4 (sites S39, S40, and S4) were closer to Zone 1 than their western counterparts, indicating that the species composition of the eastern faunal zones, or the east side of Zone 4, was shifted to resemble Zone 1 . The assignment of Hipro to Zone 1, MT3 to Zone $2 \mathrm{E}$, and S39 to Zone 4 may seem somewhat arbitrary in the 2D MDS ordination (Fig. 3). However, a more detailed 3D MDS ordination (3D stress $=0.13$ ) confirmed that the cluster analysis (Fig. 2) allocated the faunal zones properly. Based on the results of cluster analysis and MDS, a map of deep-sea macrofaunal zones in the northern GoM can be generated (Fig. 4) in which the zones are separated by proposed boundaries. Note that WC5 and GKF are independent and do not belong to any zones.

Zone 1 was a narrow ribbon extending from 213 to $542 \mathrm{~m}$ with an apparent submergence to $1572 \mathrm{~m}$ at Hipro. 
Zone 2 was separated into an east (Zone 2E, 625 to $1828 \mathrm{~m}$ ) and west subzone (Zone 2W, 863 to $1620 \mathrm{~m}$ ). Zone 3 was separated into 2 subzones with the east zones (Zone 3E, 2275 to $3314 \mathrm{~m}$ ) extending deeper than the west zone (Zone 3W, 2042 to $3008 \mathrm{~m}$ ). Zone $3 \mathrm{~W}$ covered the most complex bathymetric features in northern GoM, including the Alaminos Canyon (AC1), basins (B1-2), non-basins (W5, NB3-5), and the base of the Sigsbee Escarpment (RW6). However, these sites showed no indication that they affected the zonal distribution (no significant groups). Zone 4 (2954 to $3732 \mathrm{~m}$ ) occupied the abyssal plain (S1-S4) and the base of the Florida Escarpment (S39, S40).

The 5 species contributing the most to each faunal zone are shown in Table S2 in the Supplement, based on SIMPER, and Table S3, based on abundance. In Zone 1, the 5 most dominant species that accounted for $53.9 \%$ of abundance contributed only a total of $5 \%$ to the average similarity. For example, the most abundant species of amphipod, Ampelisca mississippiana, occurred mostly in Zone 1 and was relatively sparse in Zones 2W, 2E, and 3. However, $99 \%$ of the specimens (15851 ind. $\mathrm{m}^{-2}$ ) were only found at the head of the Mississippi Canyon (MT1), suggesting a patchy distribution (Soliman \& Wicksten 2007). In Zones 2E, 2W, $3 \mathrm{E}, 3 \mathrm{~W}$, and 4 , the species that contributed the most to the average similarities and to abundance were largely repeated; thus, the dominant species were more evenly distributed. Some species made large contributions to average faunal similarities in more than 1 faunal zone. In other words, zonation was less obvious.
For example, the polychaete Tharyx marioni was important to Zones 1, 2W, and $3 \mathrm{E}_{\text {; }}$ the bivalve Heterodonta sp. $B$ contributed largely to Zones $3 \mathrm{E}, 3 \mathrm{~W}$, and 4 ; and the polychaete Aricidea suecia contributed significantly to Zones 1, 2E, and 2W. Two polychaetes (Levinsenia uncinata, Paraonella monilaris) were important species in the most faunal zones, with the former contributing to Zones 1, 2E, 2W, and 3W and the latter to Zones 2W, 3W, 3E, and 4. One of the characteristic species in Zone 4, the bivalve Vesicomya vesica, has been considered an indicator for cold-seep communities (Sibuet \& Olu 1998). To our surprise, this species was distributed throughout our sampling area (in 29 out of 51 locations), even on the abyssal plain.

SIMPER was also performed to break down the average dissimilarity between independent stations and their adjacent faunal zones (Table S4 in the Supplement). The species that only appeared in GKF but not in Zones 3W or 3E seemed to contribute extensively to the dissimilarity between GKF and the adjacent zones. Between Zone 1 and WC5, 2 polychaete Prionospio species had the highest contributions to the average dissimilarity. Most species that had high contributions to the dissimilarities were more abundant in WC5 than in Zone 1.

In the SIMPER analysis, polychaete species appeared to be the most important taxon. The importance of bivalve species, however, increased from Zones 3E and 3W toward the deeper Zone 4 (Table S2, Fig. 5). The isopods were the third most important taxon, with the contribution increasing slightly across Zones 1 to 4 .

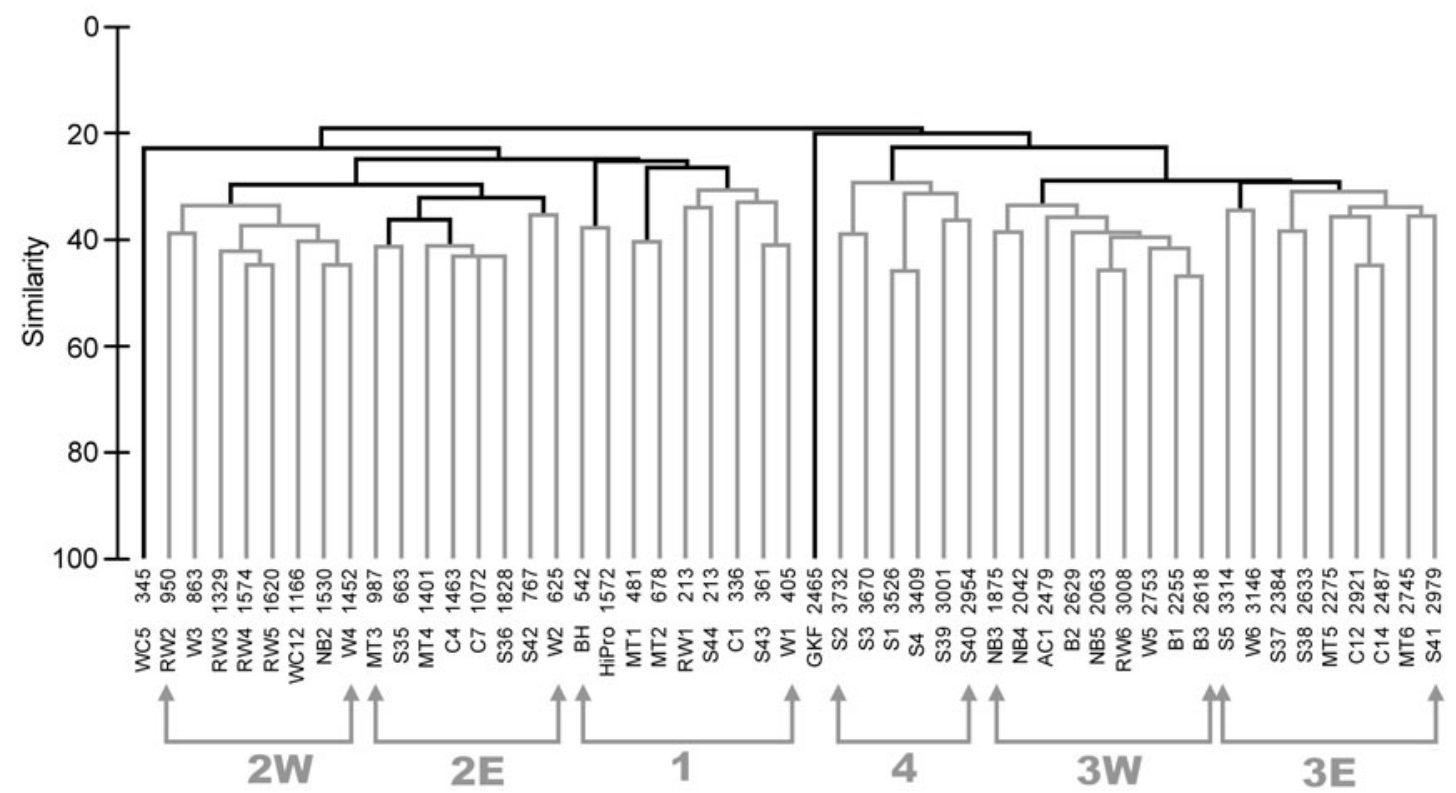

Fig. 2. Group-average cluster analysis on faunal resemblance. The abundance of each species was 4th-root transformed before calculating Bray-Curtis similarity. Black branches indicate significant faunal groups where the similarity profile (SIMPROF) test $(p<0.05)$ suggested that the structure is not random. The $x$-axis shows faunal zones, station name, sampling depth $(\mathrm{m})$. The $y$-axis shows Bray-Curtis similarity $(\%)$ 


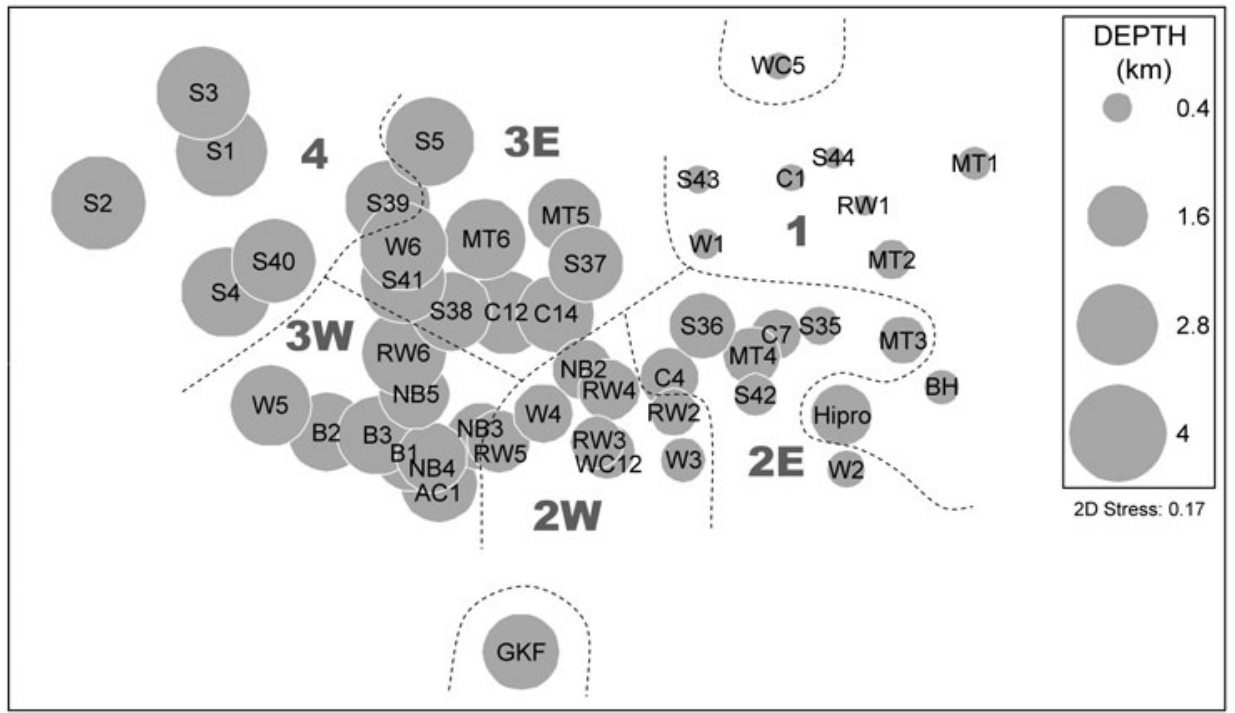

Fig. 3. Non-metric multidimensional scaling (nMDS) ordination of Bray-Curtis faunal similarity. The faunal similarity between sites is represented by the relative distance. Bubble size shows relative water depths. Faunal zones are separated by dotted lines

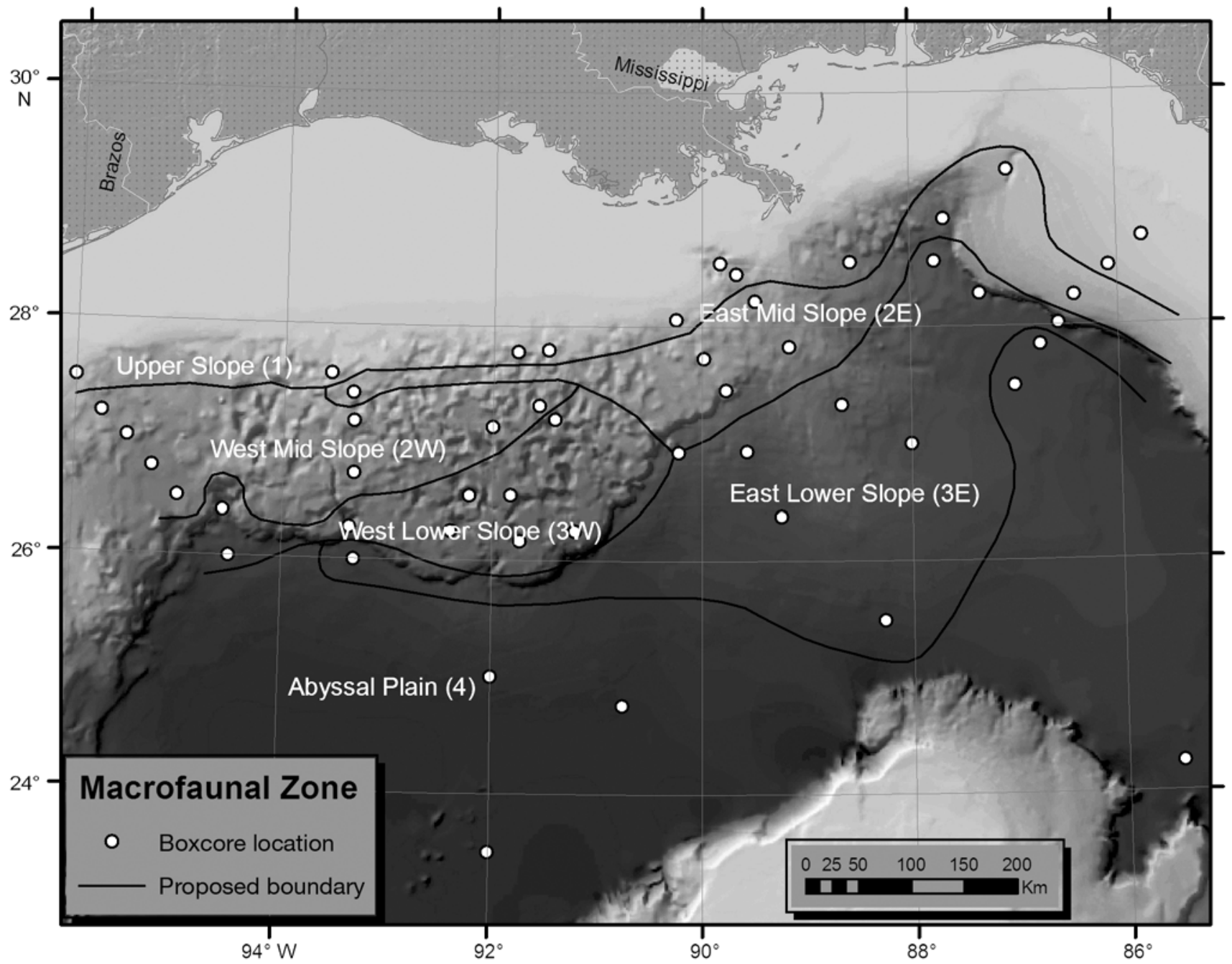

Fig. 4. Locations and extent of macrofaunal zones determined by cluster analysis (see Fig. 2). The proposed boundaries (thick black lines) follow the midpoints between 2 adjacent zones. WC5 and GKF are not included in any faunal zone. Box core labels given in Fig. 1. Fig. derived from French \& Schenk (2006) 
The species can also be categorized based on the breadth of their distribution with depth, with 'stenozonal' species occupying narrow ranges and 'euryzonal' species occupying broad ranges. The stenozonal species restricted to a single zone can then be compared to the euryzonal species that co-occurred throughout all zones, and the slope species that cooccurred in Zones 1, 2E, 2W, 3E, and 3W (Fig. 6). Zones 1 and $2 \mathrm{E}$ had the most stenozonal species and the fewest euryzonal species, whereas Zones $3 \mathrm{~W}$ and 4 had the most euryzonal species and fewest stenozonal species. The combination of the slope and euryzonal species accounted for $26 \%$ to $40 \%$ of the species in Zones 3E, 3W, and 4, suggesting that species with wide ranges dominated the lower slope and abyssal plain.

\section{Linking environmental variables to faunal zonation}

The trace metals were reduced by PCA to 2 principal component (PC) axes $(78.5 \%$ of total variance explained). PC1 had roughly equal contributions from $\mathrm{Ca}, \mathrm{Be}, \mathrm{Al}, \mathrm{Ti}, \mathrm{Zn}, \mathrm{Fe}, \mathrm{V}, \mathrm{Cr}, \mathrm{Si}, \mathrm{Ba}, \mathrm{Mg}, \mathrm{Mn}$, and $\mathrm{Ni}$. PC2 was dominated by $\mathrm{Cu}$ and $\mathrm{Sr}$, as well as other lesser important elements, including $\mathrm{Na}, \mathrm{Ni}, \mathrm{Ca}, \mathrm{Ba}$, and $\mathrm{Mg}$. The trace metal PC1 (MET1) and PC2 (MET2) were then combined with the other 12 variables (Table 1). One-way ANOSIM suggested that the multivariate environmental data were significantly different among the faunal zones $(\mathrm{R}=0.33, \mathrm{p}<0.001)$ and the pairwise tests were significant between most pairs of zones $(p<0.01)$. A PCA of the 14 environmental variables showed a continuous change of seabed properties with slightly overlapping stations between the adjacent zones (Fig. 7). The first 2 PC axes explained $72.1 \%$ of the total variance. MET1 dominated the PC1 axis. MET2, depth, and dissolved oxygen had the highest positive loading on the PC2 axis, while export POC flux and temperature had the largest negative loadings.

The intra-location distance of 14 environmental variables had a significant correlation with faunal resemblance (RELATE, $\rho=0.44, \mathrm{p}<0.001$ ). The individual correlation (RELATE) on each variable suggested that the export POC flux had the highest correlation with the faunal resemblance matrix $(\rho=0.70, p<0.001)$, followed by water depth $(\rho=0.67, p<0.001)$ and the other 8 variables (Table 1). The total PAH concentration, relative backscatter, particulate material concentration, and percent clay content were not significantly correlated with the faunal resemblance $(p>0.05)$. The best subsets of environmental variables were combinations of export POC flux, depth, relative fluorescence, dissolved oxygen, MET2, percent sand, and temperature (Table 2).

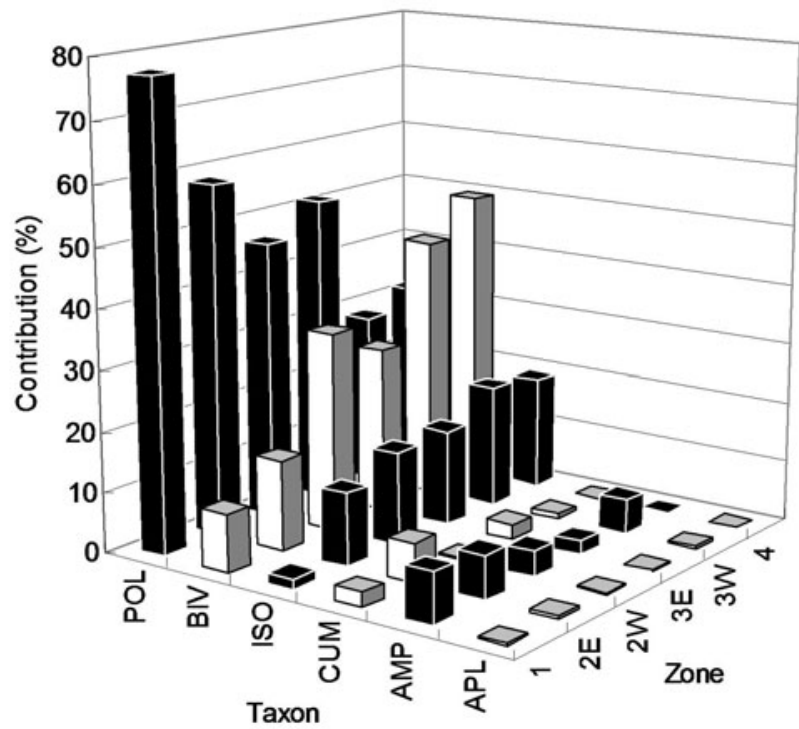

Fig. 5. Percent taxon contribution to faunal zonation based on similarity percent contribution (SIMPER) analysis. The average Bray-Curtis similarities within faunal zones were broken down to percent contributions for polychaetes (POL), bivalves (BIV), isopods (ISO), cumaceans (CUM), amphipods (AMP), and aplacophorans (APL)

When the RELATE analysis was restricted to the zones of similar depths, such as the subzones of Zones 2 or 3 (Table 3), the export POC flux remained the most important correlate of faunal resemblance for Zone 2 $(\rho=0.51, p<0.001)$ and for Zone $3(\rho=0.27, p=0.01)$, while depth fell to the 4 th best correlate for Zone 2 ( $\rho=$ $0.38, p=0.02$ ) and the 6th best correlate for Zone 3 ( $\rho=$ $0.18, p=0.04$ ). The top 6 environmental variables for Zones 2 and 3 (Table 3) were plotted against the

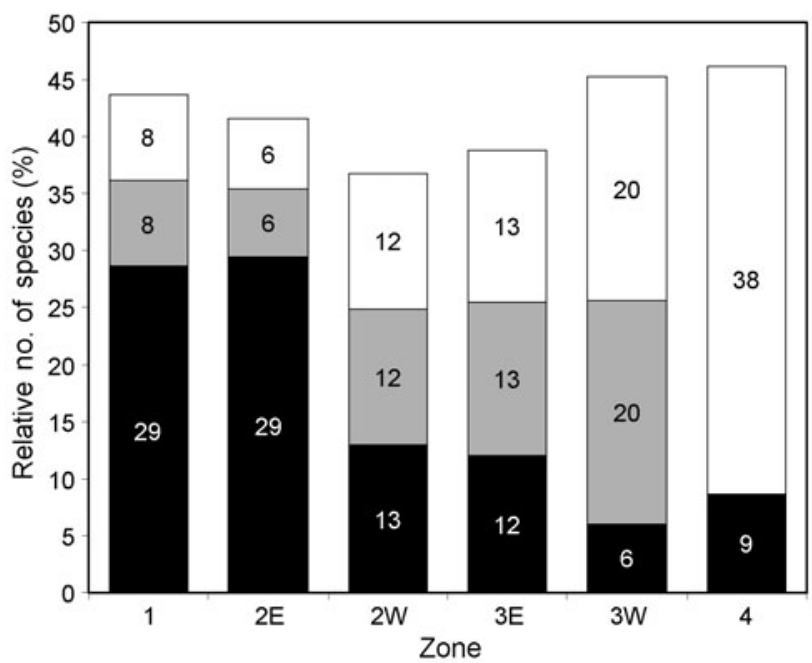

Fig. 6. Number of euryzonal, slope, and stenozonal species relative to the total numbers of species in each zone. Black, gray, and white bars: percentages of stenozonal, slope, and euryzonal species, respectively 
Table 2. BIO-ENV analysis, showing that the 10 best subsets of environmental variables give the highest correlations in the RELATE test. The Spearman's rank correlation coefficient was calculated between the subset of variables and faunal similarity. Variables defined in Table 1

\begin{tabular}{|ll|}
\hline Correlation $(\rho)$ & Variables \\
\hline 0.722 & DEP, POC \\
0.715 & DEP, POC, FLU \\
0.697 & POC \\
0.687 & DEP, POC, DO, FLU \\
0.681 & DEP, POC, FLU, MET2 \\
0.68 & DEP, POC, MET2 \\
0.679 & DEP, POC, DO, FLU, MET2 \\
0.679 & DEP, POC, FLU, SAN \\
0.676 & DEP, POC, TEM, FLU \\
0.674 & DEP, POC, DO, FLU, SAN \\
\hline
\end{tabular}

respective subzones (Fig. 8). A Student's t-test suggested that out of 6 variables, only the export POC flux $(t=2.60, \mathrm{df}=9.03, \mathrm{p}=0.03)$ was significantly different between Zones 2E and 2W (Fig. 8a). Between Zones $3 \mathrm{E}$ and $3 \mathrm{~W}$, percent sand content $(t=2.29$, df $=8.37, \mathrm{p}<$ $0.05)$ and MET1 $(t=2.24, \mathrm{df}=12.25, \mathrm{p}=0.04)$ were significantly different (Fig. 8i \& k). The concentration of Ca was significantly higher in Zone $3 \mathrm{E}$ than in Zone $3 \mathrm{~W}(t=2.30, \mathrm{df}=13.63, \mathrm{p}=0.04)$. The concentrations of $\mathrm{Al}, \mathrm{Ba}, \mathrm{Be}, \mathrm{Cr}$, and $\mathrm{Mg}$ were significantly lower in Zone $3 \mathrm{E}$ than in Zone 3W ( $t$-test, $\mathrm{p}<0.05)$. However, none of the trace metals was considered to be in high enough
Table 3. RELATE tests restricted to Zone 2 ( $E$ and $W$ ) or Zone 3 ( $\mathrm{E}$ and $\mathrm{W}$ ) on the selected environmental data. A Spearman's rank correlation coefficient was calculated between individual variables and faunal similarity of Zone 2 or Zone 3. Variables are defined in Table 1

\begin{tabular}{|c|c|c|c|c|c|}
\hline \multicolumn{3}{|c|}{ Z Zones 2E \& W- } & \multicolumn{3}{|c|}{- Zones 3E \& W - } \\
\hline Variable & $\rho$ & $\mathrm{p}$ & Variable & $\rho$ & $\mathrm{p}$ \\
\hline POC & 0.511 & $<0.001$ & POC & 0.27 & 0.008 \\
\hline DO & 0.437 & $<0.001$ & MET2 & 0.257 & 0.024 \\
\hline TEM & 0.437 & $<0.001$ & SAN & 0.25 & 0.012 \\
\hline DEP & 0.38 & 0.002 & SAL & 0.232 & 0.037 \\
\hline SAL & 0.283 & 0.011 & MET1 & 0.195 & 0.034 \\
\hline SAN & 0.24 & 0.026 & DEP & 0.178 & 0.043 \\
\hline $\mathrm{BAC}$ & 0.223 & 0.020 & FLU & 0.173 & 0.059 \\
\hline CLA & 0.216 & 0.023 & BAC & 0.109 & 0.182 \\
\hline SLT & 0.168 & 0.058 & CLA & 0.095 & 0.237 \\
\hline MET1 & 0.134 & 0.144 & PM & 0.08 & 0.259 \\
\hline PAHs & 0.107 & 0.158 & SLT & 0.047 & 0.355 \\
\hline MET2 & 0.068 & 0.286 & TEM & -0.041 & 0.650 \\
\hline PM & 0.047 & 0.339 & PAHs & -0.068 & 0.702 \\
\hline FLU & 0.025 & 0.375 & DO & -0.116 & 0.882 \\
\hline
\end{tabular}

concentration to adversely affect the benthic biota (Wade et al. 2008). The high correlation of trace metals to faunal resemblance might be a result of collinearity between trace metals and the silt-clay fraction nearshore.

The water depth and export POC flux were selected by BIO-ENV as the optimal subset of variables that

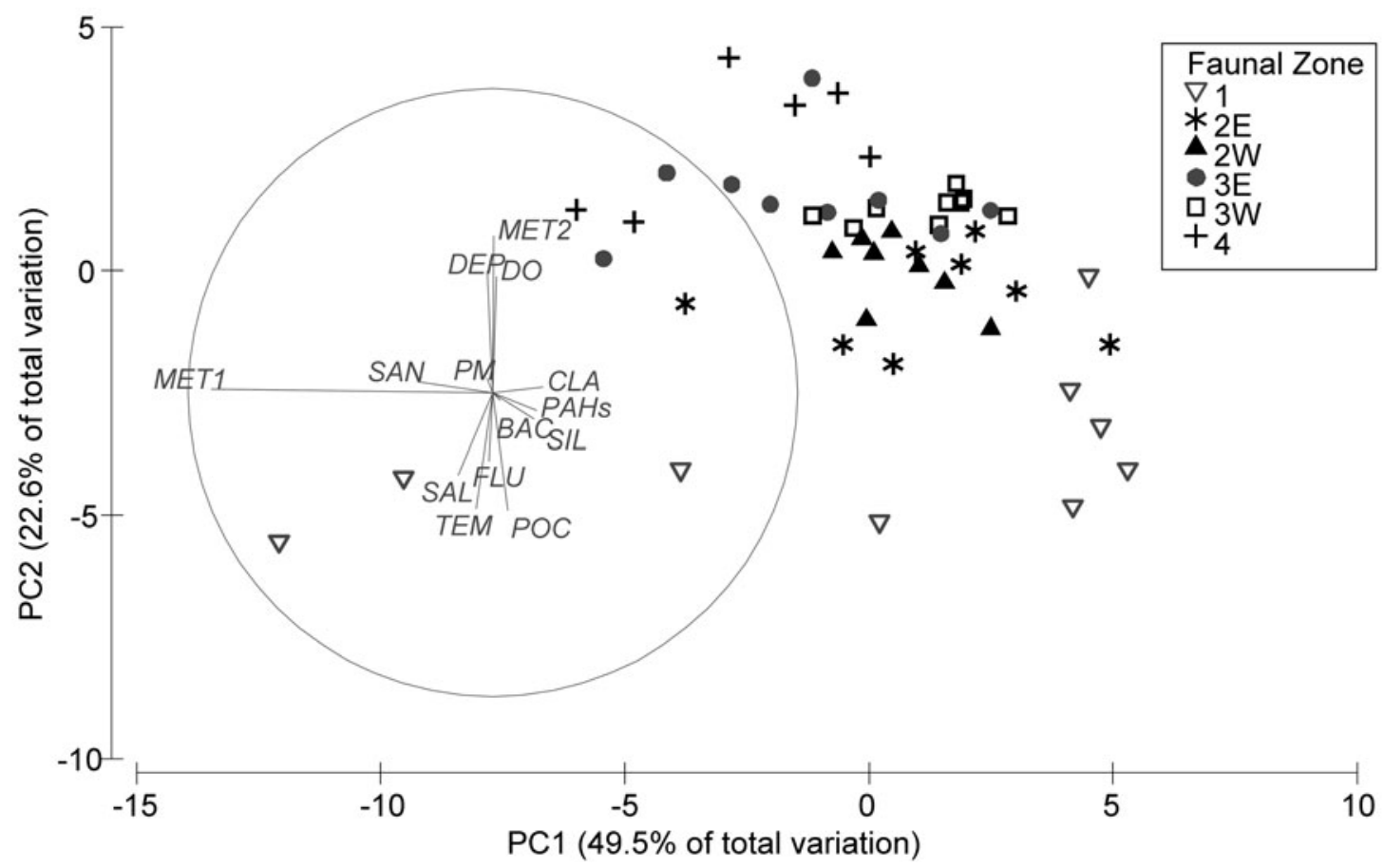

Fig. 7. Principal component analysis (PCA) of all 14 environmental variables. The environmental data were logarithm transformed and normalized before computing Euclidean distances. The symbols indicate the faunal zones indentified by cluster analysis (see Fig. 2) 
gave the best match to faunal resemblance $(\rho=0.722)$. LINKTREE analysis was conducted for 49 sites (Fig. 9). Even though the export POC flux was selected as the best individual variable by RELATE (Table 1), water depth occupied more divisions (11 times) than export POC flux (8 times) in LINKTREE. Generally, the natural grouping in the LINKTREE matched the predefined zones (Fig. 2). In Fig. 9, the matched sites are highlighted (bold letters) and the names of the respective faunal zones (gray text boxes) are underneath each group. The first split (A) was explained by depth, separating the Sigsbee Abyssal Plain (S1, S2, S3, depth $\geq 3.53 \mathrm{~km}$ ) from the rest of the sites (depth $\leq 3.41 \mathrm{~km}$ ). It is also a natural division on the MDS ordination (Fig. 3). The export POC flux determined the second split (B) and obliquely divided the northern GoM in half. The right partition (POC flux $\geq 10.3 \mathrm{mg} \mathrm{C} \mathrm{m}^{-2} \mathrm{~d}^{-1}$ ) includes the upper and east mid-slope (Zones 1 and $2 \mathrm{E}$ ). The left partition (POC flux $\leq 9.5 \mathrm{mg} \mathrm{C} \mathrm{m}^{-2} \mathrm{~d}^{-1}$ ) includes the lower and west mid-slope (Zones 2W, 3E, and $3 \mathrm{~W}$ ) as well as 2 deep sites at the central (S5) and the southeast GoM (S4). The third split (C) suggests that the abyssal plain community (Zone 4) is best defined by depth $\geq 3.31 \mathrm{~km}$ or POC flux $\leq 3.1 \mathrm{mg} \mathrm{C} \mathrm{m}^{-2}$ $\mathrm{d}^{-1}$. The communities on the lower and west mid-slope (Zones 2W, 3E, and 3W) fell within the POC flux range between 3.7 and $9.5 \mathrm{mg} \mathrm{C} \mathrm{m}^{-2} \mathrm{~d}^{-1}$. A range of charac- teristic environmental variables can be generated for each zone as the binary division proceeds (Table 4). However, the natural grouping in LINKTREE is not identical to the original dendrogram (Fig. 2). The detailed environmental threshold in each zone should be considered a parsimonious explanation.

The environmental variables were superimposed on the MDS ordination with the size of the bubble denoting the magnitude of a given environmental value. A distinct zonal pattern was observed for the export POC flux, with clear between-zone and small within-zone variation (Fig. 10). Water depth was highly correlated ( $\rho=0.67, p<0.001$ ) with faunal resemblance, but no difference was apparent between the east zones (2E, $3 E)$ versus west zones $(2 \mathrm{~W}, 3 \mathrm{~W})$. The higher export POC flux to Zone $2 \mathrm{E}$ than to $2 \mathrm{~W}$ may be important in explaining horizontal zonation.

\section{DISCUSSION}

The separation of east and west zones on the midand lower slope suggested a horizontal zonation caused by an east-west environmental gradient. Evidence that included a significantly distinct faunal group at the head of the Mississippi Trough (MT1 and MT2), a submergence zone on the eastern, upper slope
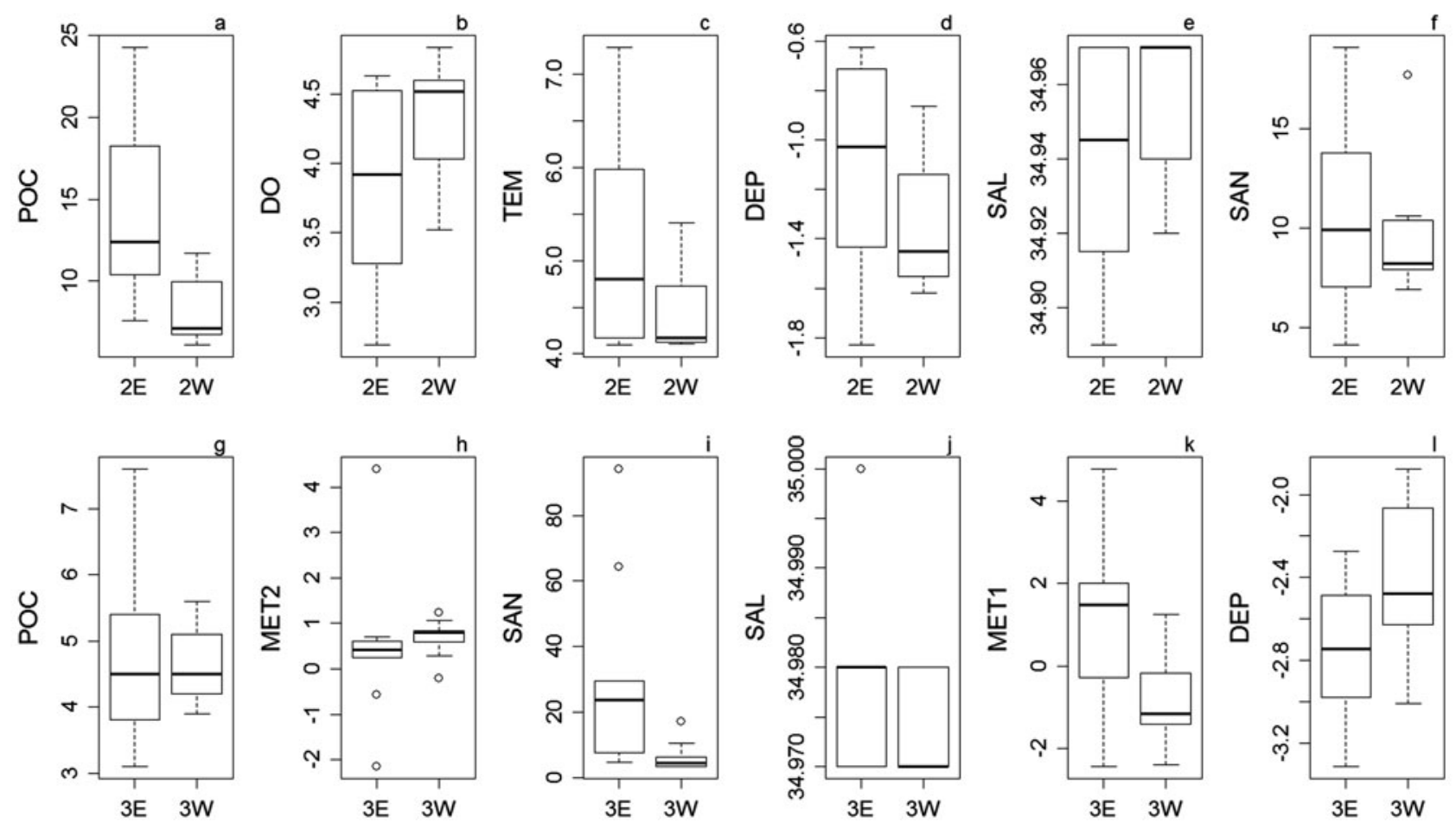

Fig. 8. Zones 2E and 2W for (a) export POC flux, (b) dissolved oxygen, (c) temperature, (d) depth, (e) salinity, and (f) percent sand; and Zones 3E and 3W for (g) export POC flux, (h) trace metal PC2, (i) percent sand, (j) salinity, (k) trace metal PC1, and (l) depth. The thick line indicates median; lower and upper hinges indicate 25 and $75 \%$ quartiles; whiskers indicate the minimum and maximum values; open circles indicate outliers 


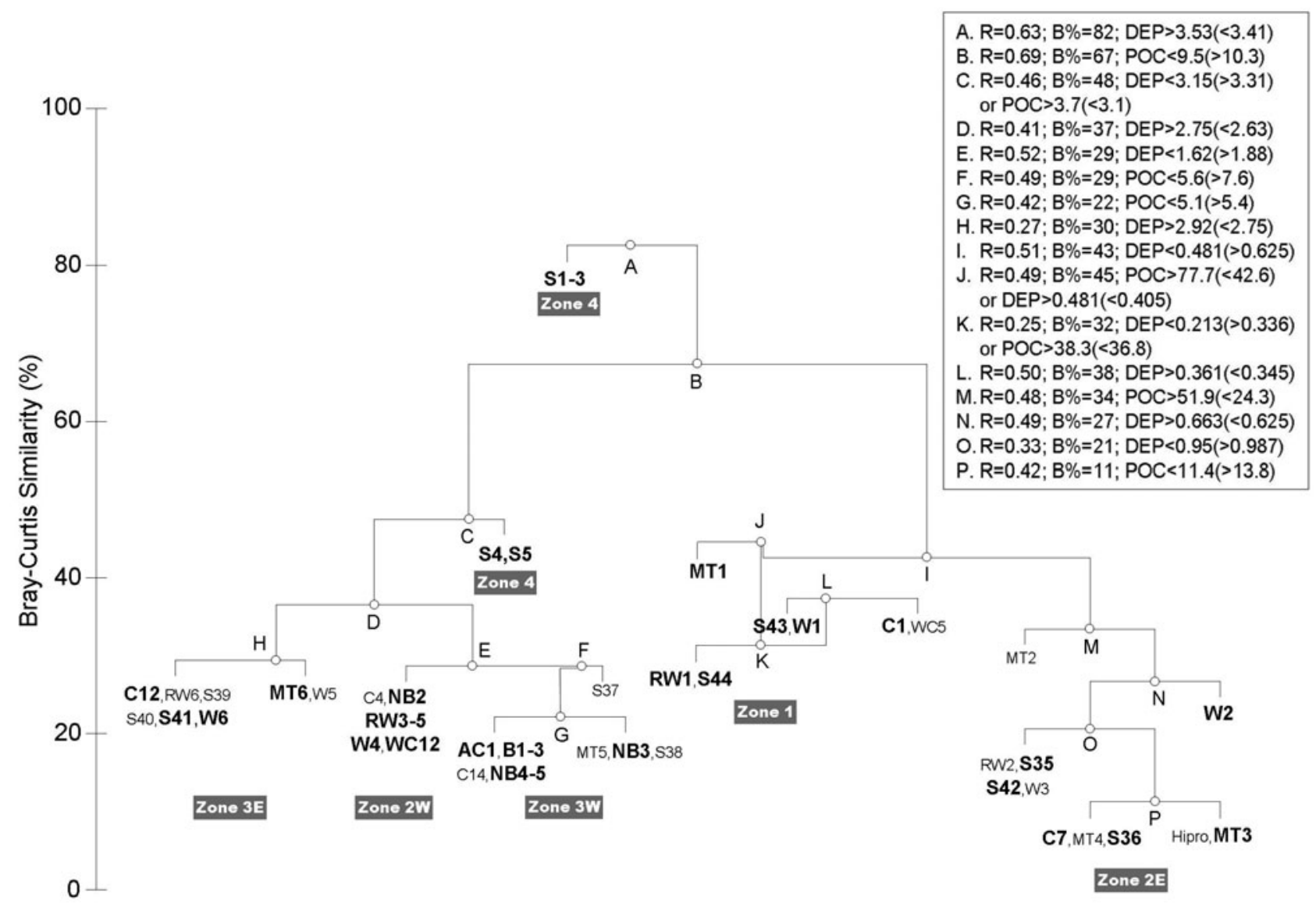

Fig. 9. Linkage tree analysis (LINKTREE), showing binary clustering of sites based on species composition and constrained by the threshold of water depths $(\mathrm{km})$ or export particulate organic carbon (POC) fluxes $\left(\mathrm{mg} \mathrm{C} \mathrm{m}^{-1} \mathrm{day}^{-1}\right)$. An optimal analysis of similarity (ANOSIM) R value (largest group separation) was selected from all possible divisions between any 2 environmental values. The successive division stopped when a similarity profile (SIMPROF) test suggested that the branch was not significant ( $\mathrm{p} \geq 0.05$ ). The stations matched to the pre-defined faunal zones (gray text boxes) are highlighted in bold. In the text box key, each division $(\mathrm{A}, \mathrm{B}, \mathrm{C} \ldots$ ) is followed by an ANOSIM R value, Bray-Curtis similarity (B\%), and a range of environmental values explaining the division. The first inequality defines the branch to the left and the second inequality (in brackets) indicates the branch to the right

(Hipro) and central GoM (S5), as well as a shift in faunal composition in the east faunal zones toward one that more closely resembled the upper-slope community, also suggests a potential influence of the Mississippi River and the adjacent canyon. In the summers, mesoscale eddies can generate cross-margin flows and move low-salinity, high-chlorophyll Mississippi River water off the shelf into the deep eastern GoM, which can lead to high POC input to the seabed (Biggs et al. 2008, Jochens \& DiMarco 2008). This input was evident for the mid-slope zones, where the export POC flux was significantly higher in Zone $2 \mathrm{E}$ than in Zone $2 \mathrm{~W}$. On the lower slope zones, the east-west difference of export POC flux was not evident. The satellite-based export POC, however, only estimated the pelagic source of sinking POC from plankton. The labile sedimentary organic matter originating from the Mississippi River plume can also be rapidly transported through the upper Mississippi Canyon via turbidity flows or mass wasting processes (Bianchi et al. 2006) and potentially to the lower part of the Mississippi
Canyon and sediment fan (Balsam \& Beeson 2003, Morse \& Beazley 2008). This lateral or down-slope transport of organic carbon can contribute a substantial fraction of the total POC input to the deep GoM basin (Rowe et al. 2008a). In fact, on the lower part of the Mississippi Sediment Fan (S5), macrofaunal biomass was more than 5 times higher than the adjacent abyssal sites at similar depths (Rowe et al. 2008b), while the export POC flux (Biggs et al. 2008) did not indicate any difference. The submergence of Zone 3E on the lower Mississippi Sediment Fan suggests that the depth-dependent decay model (Pace et al. 1987) may underestimate export POC flux. Lateral downslope transport of material can be added to the estimate of export POC flux as suggested by Rowe et al. (2008a), and this addition would influence the eastwest difference observed on the lower slope.

An unusual feature of Zones 2E and 3E is a narrow extension to the western GoM (Fig. 4). The extension of Zone $2 \mathrm{E}$ coincides with a continuous band of finegrained Mississippi sediment extending west along the 
Table 4. Thresholds of water depths $(\mathrm{km})$ or export particulate organic carbon (POC) flux ( $\left.\mathrm{mg} \mathrm{C} \mathrm{m}^{-1} \mathrm{~d}^{-1}\right)$ in each faunal zone based on LINKTREE analysis. DEP: water depth $(\mathrm{km})$

\begin{tabular}{|lll|}
\hline Faunal zones & Environmental thresholds & Division \\
\hline Upper slope (Zone 1) & POC $\geq 10.3$ and DEP $\leq 0.481$ & Split I to left \\
East mid-slope (Zone 2E) & $10.3 \leq$ POC $\leq 24.3$ & Split M to right \\
West mid-slope (Zone 2W) & $3.7 \leq$ POC $\leq 9.5$ and DEP $\leq 1.62$ & Split E to left \\
West lower slope (Zone 3W) & $3.7 \leq$ POC $\leq 5.6$ & Split F to left \\
East lower slope (Zone 3E) & $3.7 \leq$ POC $\leq 9.5$ and DEP $\geq 2.75$ & Split D to left \\
Abyssal plain (Zone 4) & DEP $\geq 3.31$ or POC $\leq 3.1$ & Split C to right \\
\hline
\end{tabular}

unlike earlier studies of single taxa or which included only the more common species in the analysis, we analyzed the complete macrofaunal community.

WC5 and GKF were not included in our defined faunal zones. Nonetheless, these distinct sites may contain important information on the linkage between the environment and the faunal composition. The polychaete Prionospio cristata dominated WC5 outer shelf and upper slope (Balsam \& Beeson 2003). The extension of Zone $3 \mathrm{E}$ coincides with intensified bottom currents that propagate westward along the base of the Sigsbee Escarpments (Hamilton \& LugoFernandez 2001, Oey \& Lee 2002). These are highspeed $\left(9 \mathrm{~km} \mathrm{~d}^{-1}\right)$ and short-period (peak spectra lasting 10 to $14 \mathrm{~d}$ ) continuous bottom currents that may transport organic material in the deep GoM basin (Jochens \& DiMarco 2008), potentially from the lower Mississippi Canyon and sediment fan to the western GoM along the escarpment. Likewise, such near-bottom currents can support larval transport and recruitment. This transport may also affect sediment dispersal along the Sigsbee Escarpment (Balsam \& Beeson 2003).

The low faunal association (similarity $<50 \%$, Fig. 2) may reflect an inevitable sampling error and underestimation of diversity inherent in box coring. However,
(48.3\% of total abundance) and contributed the most difference between WC5 and the adjacent UpperSlope Zone (Table S4 in the Supplement). All sites with P. cristata had high silt $(>33.9 \%)$ and clay $(>47.1 \%)$ material, which supports the previous observations that the genus Prionospio is a suspension/deposit feeder that occurs in soft muddy sediments (Jumars \& Fauchald 1977, Fauchald \& Jumars 1979). In fact, WC5 had 1 of the highest silt $(44.5 \%)$ and clay contents $(49.9 \%)$ of the sites sampled. However, several sites (MT4, Hipro, and GKF) with similar silt (44.5 45.5\%) and clay (45.5 52.9\%) contents did not include any $P$. cristata, probably due to the greater depth and potentially lower POC input. $P$. cristata was not encountered at WC5 during a previous study (Gallaway 1988). Three Prionospio species contributed only $0.9 \%$ of the total abundance in WC5. The dominant

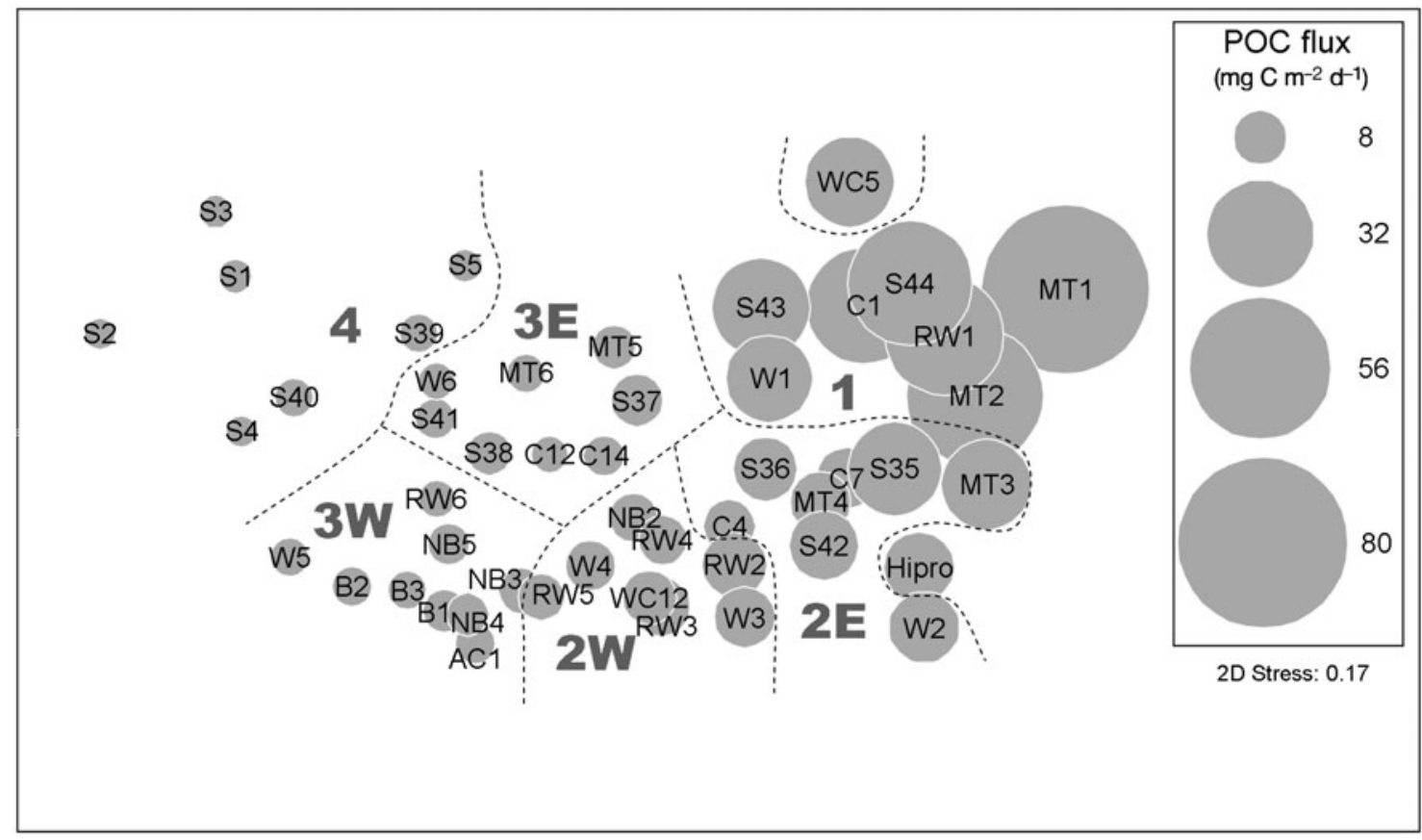

Fig. 10. Non-metric multidimensional scaling (MDS) ordination of the Bray-Curtis faunal similarity. The faunal similarity between sites is represented by the relative distance. Bubble size shows the relative export particulate organic carbon (POC) flux. Faunal zones are separated by dashed lines 
species in the previous study was Litocorsa antennata (18.2\% of the total abundance). In contrast, L. antennata was not encountered at WC5 in the current study. A dramatic change of sediment content might explain the difference, because the silt content at WC5 was only $18.6 \%$ in the previous study (Gallaway 1988).

The furrow formations in GKF were recently discovered on the sea floor at the base of Green Knoll. These mega-furrows are 5 to $10 \mathrm{~m}$ deep and 10 to $30 \mathrm{~m}$ wide, oriented parallel to the Sigsbee Escarpment, and are believed to be associated with strong near-bottom currents (Bean et al. 2002). The distinct species composition is possibly related to the unique geological feature and high-energy environment.

The presence of relatively few stenozonal species and more euryzonal species on the West Lower-Slope (Zone 3W) and Abyssal Plain Zone (Zone 4) suggests that the benthic community in the Abyssal Plain Zone represents an extension of a subset of the slope species. Similar patterns were also reported for isopods with large depth ranges cutting across zones (Wilson 2008). Rex et al. (2005) proposed a source-sink dynamics model to explain abyssal plain diversity, in which the populations are regulated and sustained by energy constraints and immigration from the continental margin. This hypothesis may explain the high contribution of bivalve species to the average faunal similarity in the Abyssal Plain Zone, since their planktonic, lecithotrophic larvae (Zardus 2002) would provide a dispersal advantage over the slope-dominated polychaete species, which are mostly brooders (Young 2003). The success of bivalves may also be due to the deposit feeding mode and the high gut to body volume ratio, which increases the sediment retention time and thus allows more complete conversion and absorption of sparse labile organic materials (Gage \& Tyler 1991). Wilson (2008) proposed that the semi-enclosed GoM basin may have experienced a Holocene extinction event that exterminated the deeper living fauna below the sill depth of $2000 \mathrm{~m}$. Under this scenario, the fauna of the Caribbean Basin would have repopulated the GoM from above the sill depth to the south. This is consistent with the observation that the midpoints of most isopod depth ranges $(79.4 \%)$ are above $2000 \mathrm{~m}(80.9 \%$ to $93.3 \%$ for the other taxa). The observed broad depth ranges of much of the fauna could then be related to ongoing process of migration to the deeper sections of the GoM.

Negative branches were observed at Split J and Split $\mathrm{L}$ in the LINKTREE analysis (Fig. 9). Clarke et al. (2008) explained the reversal as an indication that some needed explanatory variable is lacking. For example, based on a natural, non-constrained split, MT1 should be separated at Split I from the rest of the samples, due to its unique faunal composition. How- ever, the only 2 variables included in the LINKTREE, depth and POC flux, were not able to explain this split. As a result, a less natural split (lower B\%) was made prior to the more natural split (higher B\%).

The calculation of export POC flux incorporates surface production with a depth-dependent function (Pace et al. 1987). This method creates a spurious relationship between the export POC flux and any variable that is correlated with depth. However, our study suggests that the export POC flux is not only significantly correlated with the overall zonation pattern, but is the best correlate of faunal resemblance for mid- or lower slope at similar depths. For the first time, the relationship between the export POC flux and faunal zonation is distinguished independent of the depth effect.

The macroecological relationship between POC flux, water depth, and zonation presented here is a correlative approach. Causality can only be confirmed unambiguously by testing the relationship independently at other locations, such as the southern GoM or other continental margins (Kerr et al. 2007). In 2008, approximately $72 \%$ of GoM's oil production came from wells at depths greater than $300 \mathrm{~m}$, and the numbers of ultradeep platforms (1500 to $3700 \mathrm{~m})$ are increasing (Richardson et al. 2008). In addition, the community structure of deep-sea macrofauna can change over contemporary timescales with surface-ocean climate (Ruhl et al. 2008). An increase in anthropogenic activity in the deep water of the GoM and concurrent global climate change may affect benthic community structure and at the same time provide a natural experimental opportunity to test the existing pattern of faunal zonation and the underlying macroecological relationship on temporal scales.

Acknowledgements. We thank A. Ammons, C. Nunnally, L. Loughry, M. Ziegler, and X. Chen for many hours of sample sorting. We thank Captain D. Dyer and the crew onboard RV 'Gyre' for their assistance. We also thank J. Rooker, D. Thornton, P. Snelgrove, and 5 anonymous reviewers for their comments and suggestions. This research was funded by the U.S. Department of Interior, Minerals Management Service, Contract No. 1435-01-99-CT-30991. This paper is a contribution of the Continental Margin Ecosystems (COMARGE) component of the Census of Marine Life (CoML) supported by the Sloan Foundation.

\section{LITERATURE CITED}

Aldea C, Olabarria C, Troncoso JS (2008) Bathymetric zonation and diversity gradient of gastropods and bivalves in West Antarctica from the South Shetland Islands to the Bellingshausen Sea. Deep-Sea Res Part I 55:350-368

- Balsam WL, Beeson JP (2003) Sea-floor sediment distribution in the Gulf of Mexico. Deep-Sea Res Part I 50:1421-1444 Bean DA, Bryant WR, Slowey NC, Scott E, Whitehead MA (2002) Past and present furrow development in the Green 
Knoll area determined from 3D seismic data. AAPG Annual Meeting, Houston, TX

Bianchi TS, Allison MA, Canuel EA, Corbett DR and others (2006) Rapid export of organic matter to the Mississippi Canyon. Eos Trans Am Geophys Union 87, doi:10.1029/ 2006EO500002

> Biggs DC, Hu C, Müller-Karger FE (2008) Remotely sensed sea-surface chlorophyll and POC flux at Deep Gulf of Mexico Benthos sampling stations. Deep-Sea Res II 55: 2555-2562

Billett DSM (1991) Deep-sea holothurians. Oceanogr Mar Biol Annu Rev 29:259-317

Boland GS, Rowe GT (1991) Deep-sea benthic sampling with the GOMEX box corer. Limnol Oceanogr 36:1015-1020

Bray JR, Curtis JT (1957) An ordination of the upland forest communities of southern Wisconsin. Ecol Monogr 27: $325-349$

Carney RS (2005) Zonation of deep-sea biota on continental margins. Oceanogr Mar Biol Annu Rev 43:211-279

Carney RS, Haedrich RL, Rowe GT (1983) Zonation of fauna in the deep sea. In: Rowe GT (ed) Deep-sea biology, Vol 8. Wiley-Interscience, New York, p 371-398

> Cartes JE, Carrasson M (2004) Influence of trophic variables on the depth-range distributions and zonation rates of deep-sea megafauna: the case of the Western Mediterranean assemblages. Deep-Sea Res I 51:263-279

Cartes JE, Sardà F (1993) Zonation of deep-sea decapod fauna in the Catalan Sea (Western Mediterranean). Mar Ecol Prog Ser 94:27-34

> Cartes JE, Sorbe JC (1997) Bathyal cumaceans of the Catalan Sea (North-western Mediterranean): faunistic composition, diversity and near-bottom distribution along the slope (between 389 and 1859 m). J Nat Hist 31:1041-1054

Clarke KR, Warwick RM (2001) Change in marine communities: an approach to statistical analysis and interpretation, Primer-e, Plymouth

> Clarke KR, Somerfield PJ, Gorley RN (2008) Testing of null hypotheses in exploratory community analyses: similarity profiles and biota-environment linkage. J Exp Mar Biol Ecol 366:56-69

> Culver SJ (1988) New foraminiferal depth zonation of the northwestern Gulf of Mexico. Palaios 3:69-85

Culver SJ, Buzas MA (1981) Foraminifera distribution of provinces in the Gulf of Mexico. Nature 290:328-329

> Culver SJ, Buzas MA (1983) Recent benthic foraminiferal provinces in the Gulf of Mexico. J Foraminifer Res 13: 21-31

> Denne RA, Sen Gupta BK (1991) Association of bathyal foraminifera with water masses in the northwestern Gulf of Mexico. Mar Micropaleontol 17:173-193

Ekman S (1953) Zoogeography of the sea, Sidgwick \& Jackson, London

Fauchald K, Jumars PA (1979) Diet of worms: a study of polychaete feeding guilds. Oceanogr Mar Biol Annu Rev 17: 193-284

French CD, Schenk CJ (2006) Map showing geology, oil and gas fields, and geologic provinces of the Gulf of Mexico region. World Energy Assessment Team, USGS. Available at: http://pubs.usgs.gov/of/1997/ofr-97-470/OF97-470L/

Gage JD, Tyler PA (1991) Deep-sea biology: a natural history of organisms at the deep-sea floor, Cambridge University Press, Cambridge

Gage JD, Lamont PA, Kroeger K, Paterson GLJ, Gonzalez Vecino JL (2000) Patterns in deep-sea macrobenthos at the continental margin: standing crop, diversity and faunal change on the continental slope off Scotland. Hydrobiologia 440:261-271
Gallaway BJ (1988) Northern Gulf of Mexico continental slope study, final report: year 4. II. Synthesis report. US Department of the Interior, Minerals Management Service, Gulf of Mexico OCS Regional Office, New Orleans, LA

Grassle JF, Sanders HL, Smith WK (1979) Faunal changes with depth in the deep-sea benthos. Ambio Spec Rep 6: $47-50$

> Hamilton P, Lugo-Fernandez A (2001) Observations of high speed deep currents in the northern Gulf of Mexico. Geophys Res Lett 28:2867-2870

> Hecker B (1990) Variation in megafaunal assemblages on the continental margin south of New England. Deep-Sea Res A $37: 37-57$

Howell KL, Billett DSM, Tyler PA (2002) Depth-related distribution and abundance of seastars (Echinodermata: Asteroidea) in the Porcupine Seabight and Porcupine Abyssal Plain, N.E. Atlantic. Deep-Sea Res I 49:1901-1920

Jacob W, McClatchie S, Probert PK, Hurst RJ (1998) Demersal fish assemblages off southern New Zealand in relation to depth and temperature. Deep-Sea Res I 45:2119-2155

> Jochens AE, DiMarco SF (2008) Physical oceanographic conditions in the deepwater Gulf of Mexico in summer 2000-2002. Deep-Sea Res II 55:2541-2554

> Johnson NA, Campbell JW, Moore TS, Rex MA, Etter RJ, McClain CR, Dowell MD (2007) The relationship between the standing stock of deep-sea macrobenthos and surface production in the western North Atlantic. Deep-Sea Res I 54:1350-1360

Jumars PA, Fauchald K (1977) Between-community contrasts in successful polychaete feeding strategies. In: Coull BC (ed) Ecology of marine benthos. University of South Carolina Press, Columbia, SC, p 1-20

Kerr JT, Kharouba HM, Currie DJ (2007) The macroecological contribution to global change solutions. Science 316: 1581-1584

Loubere P, Gary A, Lagoe M (1993) Sea-bed biogeochemistry and benthic foraminiferal bathymetric zonation on the slope of the Northwest Gulf of Mexico. Palaios 8:439-449

Menzies RJ, George RY, Rowe GT (1973) Abyssal environment and ecology of the world ocean. Wiley, New York

Morse JW, Beazley MJ (2008) Organic matter in deepwater sediments of the Northern Gulf of Mexico and its relationship to the distribution of benthic organisms. Deep-Sea Res II 55:2563-2571

> Oey LY, Lee HC (2002) Deep eddy energy and topographic Rossby waves in the Gulf of Mexico. J Phys Oceanogr 32: 3499-3527

Olabarria C (2005) Patterns of bathymetric zonation of bivalves in the Porcupine Seabight and adjacent Abyssal plain, NE Atlantic. Deep-Sea Res I 52:15-31

> Pace ML, Knauer GA, Karl DM, Martin JH (1987) Primary production, new production and vertical flux in the eastern Pacific Ocean. Nature 325:803-804

Pequegnat WE (1983) The ecological communities of the continental slope and adjacent regimes of the northern Gulf Of Mexico. Final report by TerEco Corporation for the US Department of the Interior, Minerals Management Service Gulf of Mexico OCS Office, Metairie, LA

Pequegnat WE, Gallaway BJ, Pequegnat LH (1990) Aspects of the ecology of the deep-water fauna of the Gulf of Mexico. Am Zool 30:45-64

Pérez-Mendoza AY, Hernández-Alcántara P, Solís-Weiss V (2003) Bathymetric distribution and diversity of deep water polychaetous annelids in the Sigsbee Basin, northwestern Gulf of Mexico. Hydrobiologia 496:361-370

Powell SM, Haedrich RL, McEachran JD (2003) The deep-sea 
demersal fish fauna of the northern Gulf of Mexico. J Northwest Atl Fish Sci 31:19-33

Rex MA (1977) Zonation in deep-sea gastropods: the importance of biological interactions to rates of zonation. In: Keegan BF, Ceidigh PO, Boaden PJS (eds) Biology of benthic organisms. Pergamon Press, New York, p 521-530

Rex MA (1981) Community structure in the deep-sea benthos. Annu Rev Ecol Syst 12:331-353

Rex MA, McClain CR, Johnson NA, Etter RJ, Allen JA, Bouchet P, Warén A (2005) A source-sink hypothesis for abyssal biodiversity. Am Nat 165:163-178

Rex MA, Etter RJ, Morris JS, Crouse J and others (2006) Global bathymetric patterns of standing stock and body size in the deep-sea benthos. Mar Ecol Prog Ser 317:1-8

Richardson GE, Nixon LD, Bohannon CM, Kazanis EG, Montgomery TM, Gravois MP (2008) Deepwater Gulf of Mexico 2008: America's offshore energy future. US Department of the Interior, Minerals Management Service, Gulf of Mexico OCS Region, New Orleans, LA

Rowe GT, Kennicutt MC (2008) Introduction to the Deep Gulf of Mexico Benthos Program. Deep Sea Res II 55: 2536-2540

Rowe GT, Polloni PT, Haedrich RL (1982) The deep-sea macrobenthos on the continental margin of the northwest Atlantic Ocean. Deep-Sea Res A 29:257-278

Rowe GT, Morse J, Nunnally C, Boland GS (2008a) Sediment community oxygen consumption in the deep Gulf of Mexico. Deep-Sea Res II 55:2686-2691

Rowe GT, Wei CL, Nunnally C, Haedrich R and others (2008b) Comparative biomass structure and estimated carbon flow in food webs in the deep Gulf of Mexico. Deep-Sea Res II 55:2699-2711

Editorial responsibility: Paul Snelgrove, St. John's, Canada
Ruhl HA, Ellena JA, Smith KL (2008) Connections between climate, food limitation, and carbon cycling in abyssal sediment communities. Proc Natl Acad Sci USA 105: 17006-17011

Sibuet M, Olu K (1998) Biogeography, biodiversity and fluid dependence of deep-sea cold-seep communities at active and passive margins. Deep-Sea Res II 45:517-567

Soliman Y, Wicksten M (2007) Ampelisca mississippiana: a new species (Crustacea: Amphipoda: Gammaridea) from the Mississippi Canyon (Northern Gulf of Mexico). Zootaxa 1389:45-54

Suess E (1980) Particulate organic carbon flux in the oceans surface productivity and oxygen utilization. Nature 288: 260-263

Wade TL, Soliman Y, Sweet ST, Wolff GA, Presley BJ (2008) Trace elements and polycyclic aromatic hydrocarbons (PAHs) concentrations in deep Gulf of Mexico sediments. Deep-Sea Res II 55:2585-2593

Wei CL, Rowe GT (2009) Faunal zonation of large epibenthic invertebrates off North Carolina revisited. Deep-Sea Res II 56:1830-1833

- Wicksten MK, Packard JM (2005) A qualitative zoogeographic analysis of decapod crustaceans of the continental slopes and abyssal plain of the Gulf of Mexico. Deep-Sea Res I 52:1745-1765

Wilson GDF (2008) Local and regional species diversity of benthic Isopoda (Crustacea) in the deep Gulf of Mexico. Deep-Sea Res II 55:2634-2649

Young CM (2003) Reproduction, development and life-history traits. In: Tyler PA (ed) Ecosystems of the deep oceans. Elsevier, Amsterdam, p 381-426

Zardus JD (2002) Protobranch bivalves. Adv Mar Biol 42:1-65

Submitted: April 14, 2009; Accepted: October 19, 2009

Proofs received from author(s): December 27, 2009 